\title{
Mereposisi Hubungan Agama dan Negara di Indonesia dalam Perspektif Iman Kristen
}

\author{
Osian Orjumi Moru \\ Institut Agama Kristen Negeri Kupang, Nusa Tenggara Timur \\ osianmoru@gmail.com
}

\begin{abstract}
The relationship between religion and state must be seen in terms of constructive and contextual relations. This means that the relationship between religion and the state is built on the basis of a common vision to create complete human life. This article is a qualitative research literature using a descriptive analysis method about the political and national situation in Indonesia as a context for finding the relationship between religion and the state. Religion and the state are both servants of God in bringing prosperity and justice to all humanity. This framework of thinking has logical consequences in repositioning the relationship between religion and the state in a more inductive form based on historical facts and social realities of society. In the end, placing Pancasila as an empirical reality of Indonesian society was formed in the process of the nation's history. Pancasila was formed as an effort based on the common awareness of all components of the nation to harmonize religious values and national values that are different in the Indonesian-Indonesian framework.
\end{abstract}

Keywords: Christian politics; country; Pancasila; religion

\begin{abstract}
Abstrak: Hubungan antara agama dan negara harus dilihat dalam kerangka hubungan yang konstruktif dan kontekstual. Hal ini berarti hubungan antara agama dan negara dibangun berdasarkan pada kesamaan visi untuk menciptakan kehidupan manusia yang seutuhnya. Artikel ini merupakan sebuah penelitian kualitatif literatur dengan menggunakan metode analisis deskriptif tentang keadaan politik dan nasional Indonesia sebagai konteks untuk mencari hubungan antara agama dan negara. Agama dan negara adalah sama-sama hamba Tuhan dalam mewujudkan kesejahteraan dan keadilan atas seluruh umat manusia. Kerangka berpikir tersebut membawa konsekuensi logis dalam mereposisi hubungan antara agama dan negara ke dalam bentuk yang lebih induktif berdasarkan fakta sejarah dan realita sosial masyarakat. Pada akhirnya menempatkan Pancasila sebagai suatu realita empiris masyarakat Indonesia yang dibentuk dalam proses perjalanan sejarah bangsa. Pancasila dibentuk sebagai upaya berdasarkan kesadaran bersama seluruh komponen bangsa untuk mengharmonisasikan nilai-nilai agama dan nilai-nilai kebangsaan yang berbeda-beda dalam kerangka keindonesiaan.
\end{abstract}

Kata kunci: agama; negara; Pancasila; politik Kristen

\section{Pendahuluan}

Berbicara soal hubungan antara agama dan negara telah menjadi daya tarik yang begitu menarik terutama dalam konteks kehidupan berbangsa saat ini. Realita sosial dan politik yang cenderung memiliki persepsi untuk menyatukan atau memisahkan agama dan negara terus mengemuka dalam konteks debat-debat publik yang terjadi pada media lokal maupun internasional dewasa ini. Tidak mengherankan jika ide tentang hubungan antara agama dan negara cenderung menjadi batu lompatan dalam kontestasi politik yang mengharuskan tokoh-tokoh politik berpikir keras tentang penempatan agama dalam kerangka kekuasaan 
negara. Jika dalam realita kehidupan berbangsa hubungan antara agama dan negara begitu penting, maka patut dipahami konsep tentang hubungan antara agama dan negara harus ditelisik secara mendalam dari berbagai sudut yang menempatkan baik itu agama maupun negara dalam posisi yang seharusnya. Hal ini penting dalam membangun hubungan antara agama dan negara yang bersifat konstruktif dan produktif dalam berbagai dimensi kehidupan bermasyakat kita.

Pengalaman sejarah selama berabad-abad menunjukkan bahwa corak hubungan antara agama dan negara selalu dalam dimensi yang saling memengaruhi. Realita ini menunjukkan bahwa konsep tentang hubungan agama dan negara harus dilihat dalam kacamata diskursus yang terjadi secara terus-menerus sesuai dengan konteks perubahan sosial yang terjadi. Sejarah panjang telah mencatat bahwa pada masa-masa kekuasaan tertentu negara dapat secara sistematis mengontrol dan memanfaatkan pengaruh agama bagi kepentingan politik para penguasa, tetapi juga ada masa di mana penguasa negara justru menjadi alat propaganda dari pengaruh tokoh-tokoh agama.

Misalnya dalam sejarah kekristenan, Konstantinus Agung (312) telah menempatkan hubungan yang begitu dekat antara agama dan negara. Kecenderungan saling memengaruhi antara agama dan negara terjadi secara terus menerus pada masa itu. Negara yang semula mengusai agama (gereja negara) kemudian berkembang menjadi penguasaan agama terhadap negara (corpus christianus). Pada masa setelah reformasi gereja, lambat laun agama berupaya mengambil posisi yang terpisah dari negara. Hal ini bukan tanpa alasan, sebab agama (gereja) saat itu terpinggirkan oleh kekuasaan negara dalam berbagai dimensi publik. Akhirnya agama (gereja) masa itu cenderung mengabaikan dimensi sosialnya terhadap pemerintah. Pada konteks Indonesia, hubungan antara agama dan negara kembali menjadi perdebatan panjang yang menimbulkan berbagai kegaduhan politik dan keamanan. ${ }^{1}$ Pengaruh agama yang begitu besar dalam konteks masyarakat cenderung digunakan seba-gai alat politik yang ampuh dalam menjatuhkan popularitas lawan. ${ }^{2}$ Permainan isu-isu primodial, sering menjadi senjata yang ampuh dalam meraih kemenangan dalam perebutan kekua-saan yang kemudian berakibat pada kecenderungan negara menguasai agama atau sebaliknya.

Pembahasan ini menjadi penting karena hubungan antara negara dan agama dalam konteks iman Kristen belum terlalu banyak dilakukan dibandingkan dengan perspektif agama lain, seperti Islam. ${ }^{3}$ Memang sudah ada beberapa pembahasan mengenai kepedulian

${ }^{1}$ Endang Sari, "Kebangkitan Politik Identitas Islam Pada Arena Pemilihan Gubernur Jakarta," Kritis: Jurnal Ilmu Sosial dan Ilmu Politik 2, no. 2 (2016): 145-156. Band: Edi Purwanto, "Peran Ekonomi, Politik, Dan Sosial Dalam Kekerasan Atas Nama Agama," DUNAMIS: Jurnal Teologi dan Pendidikan Kristiani 4, no. 1 (2019): 111-126.

${ }^{2}$ Cornelis Lay, "Kekerasan Atas Nama Agama: Perspektif Politik," Jurnal Ilmu Sosial dan Ilmu Politik 13, no. 1 (2009): 1-19.

${ }^{3}$ Masykuri Abdillah, "Hubungan Agama Dan Negara Dalam Konteks Modernisasi Politik Di Era Reformasi," AHKAM : Jurnal Ilmu Syariah 13, no. 2 (2013): 247-258. 
gereja terhadap politik ${ }^{4}$, seperti mendorong gereja untuk mengajarkan nasionalisme ${ }^{5}$, atau tentang merumuskan etika politik dalam perspektif Kristen. ${ }^{6}$ Namun penelitian tersebut belum memberikan sebuah sikap yang ideal tentang hubungan agama dan negara dan dapat digunakan sebagai acuan atau rekomendasi. Penelitian ini mendorong munculnya sebuah teologi kontekstual tentang hubungan antara agama dan negara.

\section{Metode Penelitian}

Adapun metode penelitian yang digunakan adalah metode deskriptif. Menurut kamus bahasa Indonesia, istilah deskriptif berarti "bersifat menggambarkan apa adanya."7 Metode deskriptif adalah jenis metode penelitian atau studi dengan memaparkan, menggambarkan atau menjelaskan dengan kata-kata secara jelas apa adanya. Beberapa prosedur yang ditempuh dengan metode deskriptif ini antara lain, mencari data lewat kitab, jurnal, software e-book, literatur-literatur lain yang berkaitan. Kemudian analisis penelitian dilakukan bersama dengan pengumpulan data yakni "proses analisis data kualitatif sebagai mengubah sifat (transforming) data mencakup tiga proses yaitu: deskripsi, analisis, dan interpretasi." Penelitian ini, berdasarkan data dan pendekatan analisa datanya, kualitatif. Penelitian kualitatif menekankan analisisnya pada proses penyimpulan deduktif dan induktif serta analisis terhadap dinamika hubungan fenomena yang diamati dengan menggunakan logika ilmiah. ${ }^{9}$

\section{Pembahasan}

\section{Mereposisi Hubungan antara Agama dan Negara}

Posisi hubungan antara agama dan negara memang menjadi hal yang diperdebatkan dari waktu ke waktu. Posisi kedudukan agama maupun negara yang tidak pada tempatnya, menjadi persoalan tersendiri bagi hubungan antara agama dan negara. Saling memengaruhi bahkan menguasai sering menjadi pemandangan biasa dalam catatan sejarah umat manusia. Keberpihakan agama maupun negara yang berlebihan satu terhadap yang lain, seringkali menghilangkan fungsi kontrol sosial dari keduanya. Masa di mana posisi agama yang cenderung dominan terhadap negara pada akhirnya membuat negara dalam konteks tertentu sulit menjalankan peranannya secara mandiri dan independen. Masa di mana negara cenderung dikontrol secara berlebihan oleh tokoh-tokoh agama dan kepentingan-nya,

\footnotetext{
${ }^{4}$ Harls Evan R. Siahaan, "Memaknai Pentakostalisme Dalam Maksud Politis Lukas: Analisis Kisah Para Rasul 1:6-8,” DUNAMIS: Jurnal Teologi dan Pendidikan Kristiani 3, no. 1 (2018): 52-73, https://sttintheos.ac.id/e-journal/index.php/dunamis/article/view/174/140.

${ }^{5}$ Harls Evan Siahaan, "Mengajarkan Nasionalisme Lewat Momentum Perayaan Paskah : Refleksi Kritis Keluaran 12 : 1-51," Dunamis : Jurnal Teologi dan Pendidikan Kristiani 1, no. 2 (2017): 140-155, https://www.sttintheos.ac.id/e-journal/index.php/dunamis/article/view/119.

${ }^{6}$ Paulus Eko Kristianto, "Dunamis : Jurnal Teologi Dan Pendidikan Kristiani Merumuskan Etika Politik Kristen Dalam Era Gangguan Terorisme Di Indonesia,” DUNAMIS: Jurnal Teologi dan Pendidikan Kristiani 3, no. 2 (2019): 223-240.

${ }^{7}$ Kamus Besar Bahasa Indonesia (KBBI) Kamus versi online/ daring (dalam jaringan), diunduh hari Rabu tanggal 14 Agustus 2019. 2004), 224.

${ }^{8}$ Subagyo, A. B,. Pengantar Riset Kuantitatif dan Kualitatif (Bandung: Yayasan Kalam Hidup,

${ }^{9}$ Yudhi Kawangung, Visio Dei: Jurnal Teologi Kristen, Diskursus Kerukunan Sosial Dalam Perspektif Masyarakat Kristen Di Indonesia: Rekonsiliasi Pasca Pemilu 2019, Luwuk Banggai, 141-160.
} 
membuat negara dijadikan sebagai alat dalam menjalankan misi agama. Negara diperalat untuk menyukseskan politik praktis tokoh-tokoh agama. Akhirnya negara akan cenderung berpihak pada satu golongan masyarakat dan mengabaikan golongan yang lainnya.

Di lain sisi, masa di mana posisi negara begitu dominan terhadap agama cenderung mengakibatkan negara kehilangan keseimbangan sosial-politik. Agama yang seharusnya menjadi alat kontrol terhadap kekuasaan negara, cenderung dibungkam oleh kepentingan ekonomi dan politik. Akibatnya cahaya agama menjadi redup dan kekuasaan negara menjadi semakin otoriter terhadap masyarakatnya. Masa dimana posisi negara yang memanfaatkan jaringan agama demi kepentingan kekuasaan dan politik, membuat terjadinya ketidakseimbangan sosial. Ketidakseimbangan sosial ini pada akhirnya membuat kekuasan negara tak terkontrol dan agama menjadi boneka negara. Melihat kedua posisi yang tidak ideal dalam perjalanan sejarah tersebut maka diperlukan suatu bentuk reposisi agama dan negara dalam konteks kekinian agar, baik agama maupun negara sama-sama dapat menjalankan fungsi dan tugasnya seideal mungkin.

Proses reposisi diperlukan agar baik agama maupun negara tidak melupakan esensi keberadaannya sebagai perwujudan citra Tuhan di dunia. Reposisi membantu agama dan negara mengenali secara mendalam panggilan diri dalam konteks suatu masyarakat. Dalam konteksnya negara dipanggil untuk menjalankan fungsi pokoknya. Fungsi negara tidak saja memegang otoritas tertinggi atas warganya, tetapi juga mengharuskan negara memberikan perlindungan sosial, ekonomi, politik dan hukum bagi seluruh warga negara tanpa diskriminasi. ${ }^{10}$ Hal ini tidak dapat ditawar-tawar. Negara harus memosisikan dirinya bukan sebagai raksasa ganas yang mengoyak rasa keadilan sosial warganya, tetapi dapat menjamin dan mengayomi keberbagaian dan hak dasar tiap warga negara tanpa memandang suku, agama dan kepercayaan.

Dalam konteks Indonesia, negara dipanggil dalam posisi yang seharusnya menjamin kebebasan beragama dan berkeyakinan sebagai hak dasar manusia yang paling fundamental. Negara tidak boleh berpihak kepada salah satu kelompok atau kepercayaan, sehingga dominasi negara sebagai hamba Tuhan menghasilkan buah kebebasan tanpa adanya paksaan dan kekerasan. Posisi yang tepat dari negara adalah bagaimana menjamin keberlangsungan kehidupan warga negara yang saling menghargai, menghormati dan memahami. Indonesia sebagai negara majemuk mengharuskan pemimpin-pemimpin negara berkontribusi dalam menjamin keadilan sosial bagi seluruh rakyatnya. Pada titik ini negara harusnya menghilangkan segala bentuk politisasi agama sehingga kepentingan politik dari rezim kekuasan tertentu tidak menjadi batu sandungan bagi persatuan dan kesatuan bangsa.

Pada sisi lain, tokoh-tokoh agama juga harus melepaskan diri dari keinginan untuk memosisikan negara sebagai alat agama tertentu. Agama sebagai lembaga maupun persekutuan harus memosisikan diri bukan sebagai penentu kebijakan negara seperti yang terjadi dalam berbagai peristiwa sejarah masa lampau, melainkan sebagai alat kontrol kehidupan

${ }^{10}$ Piter Randan Bua, David Samiyono, and Tony Christian Tampake, "Misi Gereja Dalam Mewujudkan Keadilan Sosial: Sebuah Perspektif Dari Sila Kelima Pancasila," KURIOS (Jurnal Teologi dan Pendidikan Agama Kristen) 5, no. 2 (2019): 109-124, http://www.sttpb.ac.id/ejournal/index.php/kurios/article/view/97/71. 
bernegara. Panggilan yang paling fundamental dari agama bukan sebagai penguasa atas negara melainkan menjadi "suara Tuhan" dalam kehidupan sosial masyarakat. Agama adalah kontrol sosial dalam menjamin terbentuknya masyarakat yang teratur.

Di Indonesia agama harus mampu menjaga otoritas negara dalam menjamin masyarakat yang sesuai dengan cita-cita konstitusi negara. Pemanfaatan nilai-nilai pokok dari agama seperti keadilan, kejujuran, solidaritas, gotong royong, musyawarah dan mufakat, diperlukan dalam membangun kehidupan bermasyarakat yang serba majemuk. Dalam konteks negara majemuk seperti Indonesia, agama tidak boleh tunduk dan terpengaruh pada salah satu kepentingan kelompok penguasa tertentu maupun sebaliknya. Agama harus menjadi mitra negara dalam mengupayakan terbentuknya nilai-nilai dasar hak asasi manusia. Diskusi yang kritis antara agama dan negara diperlukan untuk membatasi dan mengsinkronisasi peran-peran dari tokoh agama maupun tokoh penguasa (negarawan).

Agama dan negara harus mereposisi hubungan yang semula cenderung saling mendominasi kearah posisi yang saling melengkapi. Baik agama maupun negara memiliki panggilan yang sama yakni sebagai hamba Allah (konsep Martin Luther) dalam menciptakan keadilan sosial bagi seluruh rakyatnya. Posisi agama dan negara harus ditempatkan pada prinsip-prinsip dasar yang menjunjung kemanusiaan. Prinsip-prinsip agama harus didorong menuju ke arah yang seimbang dengan kekuasaan negara. Ini berarti baik agama maupun negara dipanggil untuk menyukseskan misi Allah dalam dunia yakni terciptanya perdamaian sosial bagi seluruh umat manusia.

Dalam posisi baru yang seimbang tersebut, negara tidak lagi tunduk kepada kepentingan salah satu agama atau golongan tertentu, melainkan kepada kepentingan seluruh umat manusia. Negara dipanggil untuk mewujudkan dan menjamin terciptanya kemanusian yang seutuhnya. Di lain sisi agama juga tidak tunduk terhadap penguasa atau rezim tertentu, melainkan mampu bekerjasama secara kritis dengan tokoh-tokoh negarawan dalam membangun suatu peradaban umat manusia yang berkeadilan sosial. Agama dipanggil menjadi alat terang dalam membangun peradaban dunia yang berdasarkan nilai-nilai ketuhanan. Agama harus menjadi alat yang dipakai Tuhan dalam memastikan terwujudnya keadilan dan kebenaran untuk seluruh umat manusia. Inilah tugas dan panggilan agama maupun negara dalam posisi yang seharusnya.

Dalam dunia yang serba modern dan penuh dengan perkembangan teknologi yang sangat pesat dewasa ini, posisi hubungan antara agama dan negara harus dipahami sebagai bentu political will masyarakatnya dalam membangun solidaritas mekanis yang berdasarkan dorongan kemanusian. Agama dan negara harus ditempatkan pada posisi yang ideal dalam hubungan yang bersifat konstruktif untuk menjamin terbentuknya nilai-nilai keIlahian. Falsafa ini dapat membantu baik itu agama maupun negara dapat mengambil peran maksimal tanpa mengurangi posisi sosial masing-masing. Dukungan yang utuh terhadap posisi yang tepat dari agama maupun negara dalam konteks masyarakat tertentu diperlukan dalam upaya serius untuk membangun suatu peradaban baru yang ideal. Agama dan negara harus berjalan dalam posisi yang seimbang dan beriringan. 


\section{Rekonstruksi Hubungan Agama dan Negara dalam Konteks Sejarah Indonesia}

Persoalan tentang hubungan antara agama dan negara di Indonesia merupakan persoalan yang panjang dan kompleks. Sekalipun bangsa ini bukanlah negara agama, keberadaan agama menjadi sesuatu yang menduduki posisi teramat penting. Peraturan perundangundangan di negara ini telah menempatkan agama pada posisi teratas dalam hubungan sosial masyarakatnya. Pasal 29 ayat 1, UUD 1945, mengatakan "negara berdasarkan ketuhanan yang Maha Esa", yang mana ini juga ditegaskan dalam sila pertama Pancasila, "Ketuhanan yang Maha Esa". Hal ini mengandung konsekuensi logis dimana hubungan antara agama dan negara selalu berada dalam proses dialektika yang panjang. Dalam sejarah panjang bangsa ini, terdapat tiga konsep penting tentang hubungan antara agama dan negara yang selalu diperdebatkan.

Pertama, pilihan negara agama. Pilihan ini menempatkan agama secara formal dalam sebuah negara. Negara berupaya mengambil ajaran dan kepercayaan salah satu agama sebagai dasar negaranya. Misalnya negara seperti Arab Saudi, Afganistan dan Qatar. Di Indonesia sendiri upaya untuk memformalisasi hubungan antara salah satu agama dengan kekuasaan negara telah berlangsung dalam sejarah yang panjang. Berbagai pergolakan politik dan keamanan dengan tujuan mendirikan negara agama berlangsung secara sporadis dalam berbagai bentuk upaya. Mulai dari upaya dengan menggunakan kekerasan seperti yang dilakukan melalui peristiwa pemberontakan DI/NII (Negara Islam Indonesia) yang dipimpin Kartosoewirjo sampai perjuangan secara politik yang dilakukan oleh sekelompok pendukung ideologi Islam pada masa pembentukan weltanschauung atau dasar negara di lingkungan BPUPKI (Badan Penyelidik Usaha-usaha Persiapan Kemerdekaan Indonesia) saat itu.

Pada masa awal kemerdekaan, Dr. Rajiman Wedyoningrat selaku ketua BPUPKI saat itu mempertanyakan tentang pembentukan dasar negara Indonesia. Kelompok pendukung ideologi Islam mengusulkan agar agama Islam menjadi dasar negara sekaligus juga menjadi agama resmi negara. Konsekuensi logisnya adalah diberlakukannya kewajiban menjalankan syariat Islam. Usulan tentang dasar negara tersebut, berakibat pada politik identitas seorang kepala negara yangdiusulkan juga harusberagama Islam. ${ }^{11}$ Persoalan ini terakumulasi secara serius dalam penerbitan Piagam Jakarta. Meski pada akhirnya rumusan Piagam Jakarta tersebut tidak digunakan sebagai dasar negara, namun usaha secara politik oleh segelintir orang untuk mengembalikan rumusan rancangan UUD pada masa BPUPKI terus berlanjut sampai saat ini.

Kedua, negara sekuler. Dalam konsep negara sekuler ini, negara secara tegas memisahkan pemikiran antara wilayah agama dan wilayah negara. Negara menempatkan agama sebagai dua wilayah yang terpisah dan berbeda. Tidak ada pencampuran soal urusan antara agama dan urusan negara. Meskipun demikian, negara tetap berupaya bertangung jawab dalam menjamin adanya kebebasan beragama dan berkepercayaan warga negara. Persoalan hubungan antara agama dan negara sebatas bagaimana mengatur kebebasan beragama tiap warga negara agar tidak saling berbenturan, tetapi persoalan tentang

\footnotetext{
${ }^{11}$ AMW Pranarka, Sejarah Pemikiran Tentang Pancasila (Jakarta: CSIS, 1988), 47 - 48.
} 
keimanan warga negara menjadi hak individu warga negara tersebut. Fokus utama dari model negara seperti ini adalah bagaimana menyejahterakan rakyatnya dalam hubungan dengan hakkonstitusional dan hak sipil warga negara. Negara tidak turut serta dalam memberikan batasan-batasan soal keimanan warga negara. Negara tidak meletakkan nilainilai agama sebagai dasar dari suatu negara.

Dalam sejarah bangsa Indonesia upaya untuk mendirikan negara sekuler semacam ini, juga terlihat jelas dalam agenda kolompok-kelompok konservatif sosialis. Timbulnya partai politik yang berbasis paham sosialis saat itu, diduga memiliki motif kuat untuk melancarkan terbentuknya negara sekuler. Dalam perjalanan sejarah bangsa ini, upayaupaya diatas kemudian terganjal oleh kuatnya gerakan kaum nasionalis dan kelompok ideologi agama yang berkembang saat itu. Konsep sekularisasi negara mendapat pertentangan keras dari berbagai golongan terutama kelompok yang mengembangkan ideologi agama. Awal dari runtuhnya usaha sekularisasi negara di Indonesia saat itu adalah dengan terjadinya peristiwa Gerakan 30September PKI, yang juga merupakan awal dari kebangkitan masa orde baru yang dipimpin oleh Soeharto.

Ketiga, negara yang didasarkan ideologi Pancasila. Pancasila adalah dasar negara yang pertama kali dicetuskan oleh Soekarno. Dalam pidatonya di hadapan Dokuritsu Junbi Cosakai atau BPUPKI, Soekarno menawarkan suatu bentuk negara yang berbeda dari dua konsepsi diatas. Konsep baru yang ditawarkan oleh Soekarno dalam pidatonya di depan BPUPKI mencakup lima sila yakni Kebangsaan, Internasionalisme, Demokrasi, Keadilan dan Ketuhanan Yang Maha Esa. Konsep tersebut kemudian dirumuskan ulang oleh tim sembilan menjadi lima pokok pikiran yang dikenal sebagai Piagam Jakarta. Namun atas usulan perwakilan Indonesia Timur dan pertimbangan penting yang dimotori oleh Hatta, maka terbentuklah suatu rumusan akhir dari dasar negara pada tanggal 18 Agustus 1945 yang kini dikenal sebagai Pancasila. Pancasila dianggap oleh para pendiri bangsa sebagai jalan terbaik dalam konsensus bersama dari kepentingan pihak-pihak yang berbeda-beda saat itu. Buah dari konsensus tersebut berakibat pada terbentuknya negara baru yang mengakomodir nilai-nilai agama dalam berbagai praktek kehidupan bermasyarakat tanpa menjadi negara agama.

Lahirnya Pancasila sebagai dasar negara juga menegaskan bahwa negara Indonesia bukan negara sekuler. Ideologi Pancasila menempatkan negara Indonesia sebagai negara yang di satu sisi menjamin warga negaranya untuk memilih kepercayaan dan beribadah menurut imannya ${ }^{12}$, tetapi juga dilain sisi menghasilkan berbagai produk hukum yang dilahirkan dari semangat nilai-nilai agama. Dengan munculnya Pancasila, Indonesia lahir sebagai negara yang berdasarkan kepada "Ketuhanan Yang Maha Esa" tanpa menekankan pada dogtrin agama tertentu. Munculnya Pancasila, merupakan landasan bersama seluruh rakyat Indonesia yang dihasilkan oleh pemikiran kritis para founding father untuk mempersatukan Indonesia secara kontekstual. Pemikiran yang kontekstual tersebut, diputuskan atas dasar konsep musyawarah-mufakat dan bukannya adu pengaruh dan

\footnotetext{
${ }^{12}$ Bua, Samiyono, and Tampake, "Misi Gereja Dalam Mewujudkan Keadilan Sosial: Sebuah Perspektif Dari Sila Kelima Pancasila.”
} 
kekuasaan. Hasil konsensus bersama inilah yang tercermin jelas dalam pidato Ir. Soekarno saat itu. Ia mengatakan: "...hasil yang dicapai itu sudah melewati pembicaraan dan masak dan sempurna..." Lebih lanjut pada bagian pidatonya yang lain Soekarno berkata: "Penitia kecil menyetujui sebulat-bulatnya rancangan preambule yang disusun oleh anggotaanggota yang terhormat..."13

Pada akhirnya, sejarah panjang perjalanan bangsa Indonesia yang menggumulkan hubungan antara agama dan negara telah berakhir dengan suatu konsensus bersama yakni Pancasila. Catatan sejarah inilah yang dapat disebut sebagai Indonesian Wisdom (Kearifan Bangsa). Catatan sejarah tersebut juga merupakan peringatan terhadap berbagai pihak yang secara sadar berupaya untuk menjadikan Indonesia sebagai negara Agama. ${ }^{14}$ Tindakan tersebut harus dilihat sebagai bentuk nyata dari penghianatan terhadap jasa-jasa para pahlawan dan sejarah perjalanan bangsa Indonesia.

\section{Hubungan antara Agama dan Negara Dalam Perspektif Ajaran Kristen}

Jika membaca teks-teks Alkitab tentang hubungan antara agama dan negara, maka akan ditemukan kondisi yang serba kompleks. Dikatkan kompleks sebab dalam catatan teks-teks tersebut, hubungan antara agama dan negara selalu berada pada posisi yang berbeda-beda bergantung pada konteks dan situasi yang membentuknya. Misalnya posisi hubungan antara negara dan agama dalam konteks Paulus. Dalam suratnya kepada jemaat di Roma, Paulus menulis: "setiap orang harus takluk kepada pemerintah yang di atasnya, sebab tidak ada pemerintah, yang tidak berasal dari Allah; dan pemerintah-pemerintah yang ada, ditetapkan oleh Allah" (Rm. 13:1). Dalam teks tersebut, Paulus dengan jelas menggambarkan pemerintah sebagai pihak yang paling berotoritas sebagai bentuk penetapan kehendak Allah.

Tulisan Paulus tersebut seolah-oleh menempatkan negara dan pemerintahnya sebagai pihak yang paling berkuasa atas berbagai aspek kehidupan masyarakat. Jika ditelisik secara harafiah, maka aroma pengukuhan atas kekuasaan negara dan pemerintah yang tak terbatas, seolah-oleh dibenarkan oleh kitab suci. Pandangan yang bersifat eksklusif seperti ini, sungguh berbahayadalam konteks negara majemuk dan demokrasi seperti Indonesia. Kekuasaan yang tak terbatas dan tak terkontrol akan cenderung menghasilkan penguasa yang sewenang-wenang kepada rakyatnya. Pandangan tersebut tentu saja perlu dicerahkan dengan konsep berpikir yang baru. Konsep berpikir yang baru adalah upaya untuk mendekostruksi teks dan kemudian merekonstruksinya agar terbangun suatu pemahaman yang menyeluruh dan kontekstual menyangkut teks-teks tersebut.

Jika perhatikan secara saksama dan inklusif, teks tersebut tidak bermaksud untuk mengukuhkan kekuasaan negara dan pemerintahnya sebagai kekuasaan yang tak terbatas. Teks tersebut sedang berbicara soal hubungan antara negara dan masyarakat, terkhusus orang-orang kristen dalam konteks pemerintahan di Roma. Hal tersebut merupakan sejenis

${ }^{13}$ Andreas A. Yewangoe, Piagam Djakarta dan Syariat Islam; Urgensi dan Konsekuensinya (Jakarta: Yayasan Bina Darma dan Nisita, 2003), 71 - 86.

14 Sonny Zaluchu, "Sudut Pandang Etika Kristen Menyikapi Pembangkangan Sipil (Civil Disobedience)," DUNAMIS: Jurnal Teologi dan Pendidikan Kristiani 3, no. 1 (2018): 24. 
ungkapan etika politik yang ditawarkan oleh Paulus bagi jemaat disana. Ungkapan tersebut muncul sebab Paulus sendiri memiliki pengalaman pribadi tentang para pejabat tinggi di Roma yang memiliki sifat bersahabat dan suka memberikan pertolongan. Konteks berpikir yang demikian, kemudian membawa Paulus pada konsep berpikir yang konstruktif tentang hubungan antara agama (Kristen di Roma) dengan negara (pemerinah Romawi) saat itu.

Dalam konsep berpikir Paulus, pemerintah yang adalah hamba Allah (ayat 4c) adalah agen-agen pembawa keadilan. Bagi Paulus pemerintah tidak dirancang untuk bertindak semena-mena kepada rakyat yang dipimpinnya (dalam konsep berpikir Paulus). Pemerintah adalah penegak hukum dan kebenaran Allah atas umat. Karenanya tidak mengherankan dan tidak berlebihan jika Paulus menggunakan suatu etika politik yang menempatkan hubungan antara umat (agama) dan pemerintah (negara) dalam konteks kepatuhan. Bagi Paulus hubungan antara agama dan negara harus ditempatkan dalam konteks kepatuhan untuk melaksanakan kebaikan. Kepatuhan tersebut dapat tercipta jika umat Allah dapat menjalankan seluruh perintah Allah dan menjauhi larangan-larangan yang bertentangan dengan hukum Allah. Negara diciptakan untuk menjadi agen Allah dalam menjaga terlaksananya kebaikan dan keadilan berdasarkan prinsip-prinsip dan nilai-nilai agama. Hal ini berarti, baik negara maupun agama memiliki peranan penting dalam menjaga panggilan sebagai hamba Allah. Cara berpikir demikian menempatkan agama dan negara dalam posisi yang saling berhubungan, selaras, konstruktif dan seimbang.

Selain pandangan Paulus di atas, Yesus sendiri juga mengajarkan adanya pemisahan yang tegas antara kekuasaan negara dengan agama. Pemisahan tersebut diungkapkan Yesus dalam Matius 22: 21, "Berikanlah kepada kaisar apa yang wajib kamu berikan kepada kaisar dan kepada Allah apa yang waajib kamu berikan kepada Allah". Melalui pernyataan ini, Yesus membuat garis batas yang seimbang antara wilayah kekuasaan negara dan agama. Pernyataan ini tidak terlepas dari konteks masyarakat saat itu yang cenderung menyamakan kaisar dengan dewa. Akibatnya garis batas antara kepentingan negara dan kepentingan agama diabaikan. Dengan pernyataanNya, Yesus berupaya menarik garis pemisah yang tegas antara kedua wilayah tersebut.

Pandangan Yesus tentang kekuasan negara dan kekuasaan agama adalah pandangan yang mengupayakan suatu proses harmonisasi antara kekuasan dunia dengan kekuasan ilahi dalam konteks kehidupan umat. Pandangan Yesus tersebut juga bertujuan untuk menghindarkan umat dari upaya mencampuradukkan atau mereduksi peranan dari salah satu wilayah kekuasaan tersebut. Bagi Yesus, baik kekuasaan agama maupun kekuasan negara harus selalu berada pada jalur yang saling terkoneksi tanpa saling berselisih. Hubungan yang saling terkoneksi tersebut menempatkan peranan agama sebagai mitra bagi penguasa negara. Alur linearitas ini harus mendorong kekuasaan agama maupun kekuasaan negara bersinergi membangun kehidupan umat manusia yang berdasarkan prinsip-prinsip kemanusiaan dan kebenaran. Bagi Yesus kerajaan sorga bukanlah suatu program politik yang meniadakan kerajaan di dunia ini. Pada hakikatnya, jawaban Yesus terhadap pertanyaan kaum Farisi dan orang-orang Herodian di atas, terkandung dasar-dasar yang berharga dalam melihat hubungan antara agama dan negara. 
Yesus dengan tegas menerangkan, bahwa hubungan antara agama dan negara harus berada dalam kerangka yang ideal. Ideal dalam arti keduanya harus terpisah dan tidak untuk dicampur-baurkan. Pemerintah duniawi tidak boleh campur tangan secara berlebihan dalam soal-soal spiritualitas umat, tidak boleh melakukan tekanan terhadap kehidupandan pikiran rohani rakyatnya; dalam hal itu tidak boleh memaksakan kehendaknyasecara agresif. Tetapi sebaliknya pula: gereja Kristus bukanlah suatu komunitas atau perkumpulan orang-orang pembuat keonaran dan berperilaku layaknya para pemberontak terhadap pemerintah duniawi. Gereja haruslah mengakui dan mendoakan pemerintahnya. Dasar berpikir inilah yang telah dipakai Yesus untuk menggambarkan dan menjelaskan hubungan yang ideal antara agama dan negara dalam konteks interaksi sosial.

Melihat pandangan Yesus diatas, maka ajaran-ajaran gereja haruslah juga bersumber pada etika berpolitik Yesus tersebut. Gereja harus memandang hubungan antara agama dan negara berada dalam posisi yang saling mendukung dan saling melengkapi dalam berbagai sisi kehidupan bersama. Inilah yang disebut sebagai kearifan dalam beragama.

\section{Gagasan Teologi Kontekstual tentang Hubungan Agama dan Negara di Indonesia}

Hubungan antara agama dan negara di Indonesia harus dibangun dengan mempertanyakan gagasan apa yang menjadi dasar dalam membangun relasi kekinian dari kedua kekuatan tersebut. Perkembangan sejarah yang menempatkan hubungan antara agama dan negara dalam kerangka yang luas, sering memposisikan baik agama maupun negara pada tempat yang tidak tepat. Hal ini terjadi sebab pemikiran-pemikiran yang terbangun tentang teologi dalam agama dan bagaimana relasinya dengan negara tidak dikonstruksi berdasarkan faktafaktalokal. Karenanya untuk membangun hubungan yang tepat antara agama dan negara dalam konteks Indonesia, harus dimulai dari upaya membangun suatu teologi yang kontekstual.

Stephen B. Bevans mengatakan bahwa suatu teologi barulah menjadi teologi apabila menjadi teologi yang kontekstual. ${ }^{15}$ Bagi Stephen, suatu teologi dapat menjadi kontekstual apabila upaya berteologi tersebut memperhatikan unsur-unsur kebudayaan dan perubahan sosial. Hal ini berarti upaya bertologi tersebut merupakan sesuatu yang kekinian sekaligus terpaut pada masa lampau. Berteologi yang demikian merupakan suatu keharusan karena dua alasan berupa faktor eksternal dan internal. Ada empat faktor ekternal yang penting untuk dibahas yakni pertama, ketidakpuasan umum yang dialami dunia pertama dan dunia ketiga terhadap pendekatan-pendekatan klasik dalam berteologi. Kedua, Pendekatan teologi yang lama bersifat menindas. Ketiga, sumbangan identitas lokal yang semakin kuat dalam pengembangan teologi. Keempat, pemahaman terhadap kebudayaan yang semakin baik akibat pengaruh ilmu-ilmu sosial. Sedangkan dalam faktor internal terdapat tiga konsep penting yakni pertama, hakikat inkarnasi dari kekristenan. Kedua, keadaan sekramental dari realitas. Ketiga, pemahaman dari pewahyuan Ilahi. ${ }^{16}$ Faktor-

\footnotetext{
${ }^{15}$ Stephen B. Bevans. Models of Conntextual Theology: Faith and Cultures (New York: Orbis Book, 1996), $1-10$.

${ }^{16}$ Ibid., 179 - 181.
} 
faktor tersebut menggambarkan upaya berteologi sebagai sesuatu yang diskontinuitas sekaligus kontinuitas. ${ }^{17}$

Dari teori tersebut, maka berbagai upaya untuk membangun teologi yang bersifat khas dalam konteks lokal akan membantu mengkonstruksi kembali hubungan antara agama dan negara dalam ajaran agama yang bersifat trasformatif. Ajaran agama yang sangat cenderung bersifat kebarat-baratan atau kearab-araban akan membawa pengaruh pada munculnya subjektifitas dan superioritas agama yang berakibat pada tidak kondusifnya hubungan sosial masyarakat suatu negara. Misalnya saja dunia barat yang cenderung mengembangkan konsep demokrasi barat dalam sistem pemerintahan mereka akan berbenturan dengan konsep dunia Arab tradisional. Hal ini akan menjadi kompleks jika kedua pemikiran yang berakar kuat dalam agama-agama yang ada, bertemu dalam konteks Indonesia yang kenyataan sosial masyarakatnya serba majemuk. Karenanya kekhasan tenunan (texture) sosial masyarakat Indonesia tidak dapat dicampuradukkan atau diperbandingkan secara apple to apple dengan konteks asli agama-agama tersebut. Perlu adanya upaya serius untuk mentransformasikan pemikiran-pemikiran agama yang lahir pada konteksnya, dengan membangun suatu bangunan pemikiran baru yang lebih persuasif dalam konteks lokal keindonesiaan pada masa kini. Jika tidak ada upaya tersebut maka gesekan dan konflik sosial dalam hubungan antara berbagai agama dan antara agama dan negara akan terjadi.

Sejarah telah mencatat bahwa gesekan menyangkut hubungan antara agama dan negara sering terjadi dalam konteks Indonesia. Contohnya saja upaya dari pihak-pihak tertentu yang ingin menggantikan dasar negara melalui tindakan kekerasan karena dianggap tidak sesuai dengan konsep ajaran agama mereka. Hal ini sering kali menjadi bumerang tersendiri bagi hubungan antara masyarakat dan hubungan antara agama dan negara. Ketidakstabilan politik dan keamanan dalam negeri menjadi tantangan berat dalam membangun suatu negara yang kuat. Jika semua agama yang ada di Indonesia hanya memiliki penganut-penganut radikal yang berpikiran secara eksklusif, maka keberlangsungan negara yang disebut Indonesia akan berada diujung tanduk. Karenanya penting untuk memastikan bahwa konsep teologi dan ideologi yang berkembang ditengah-tengah masyarakat harus menjamin keberlangsungan persatuan dan kesatuan bangsa. Demi tujuan tersebut, maka ide-ide dogmatis yang keluar dari penganut-penganut agama dalam konteks Indonesia harus digali dan dipahami dari bumi Indonesia itu sendiri. Inilah yang dimaksud dengan membangun kontekstualisasi teologi di Indonesia demi menjamin terwujudnya keberlangsungan dan keseimbangan hubungan antara agama dan negara.

Mengkontekstualisasikan teologi di Indonesia merupakan upaya sistematis untuk mewujudkan penyataan Allah dalam konteks kemajemukan. Jika ide ini dipetakan dalam gambar yang sederhana, maka hubungan antara agama dan negara dalam konteks pemikiran berteologi secara kontekstual di Indonesia harus digambarkan seperti berikut:

${ }^{17}$ Ibid., 1. 


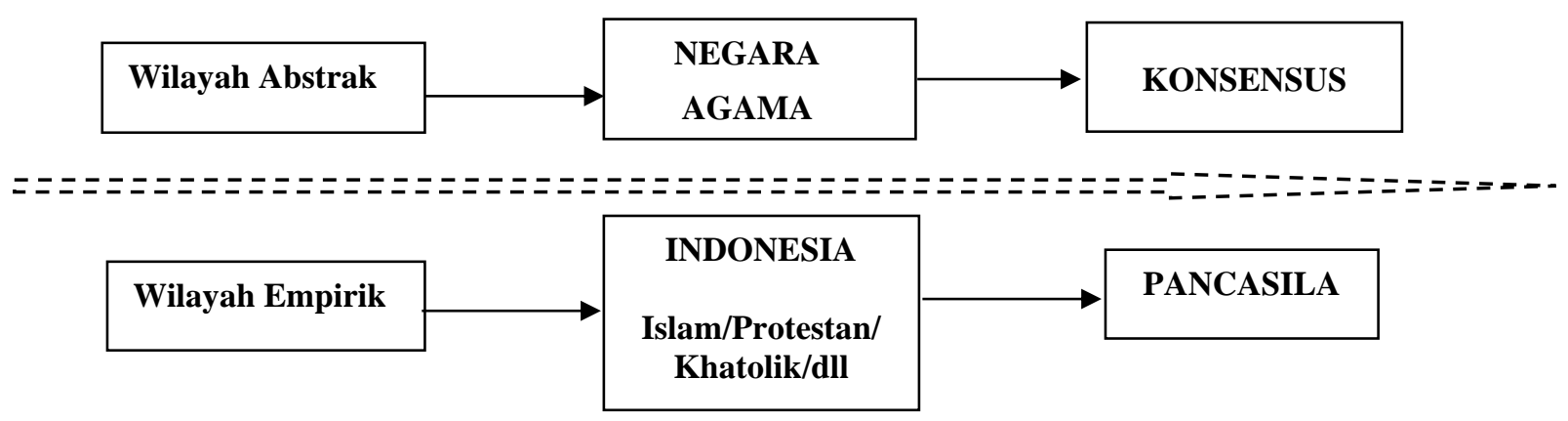

Dari gambaran di atas terlihat jelas bahwa dalam wilayah empirik, Pancasila adalah bentuk konsensus bersama yang merupakan kristalisasi nilai-nilai agama yang melambangkan hubungan harmonis dan kontekstual antara satu agama dengan agama lain, antara berbagai kepercayaan yang berbada-beda, dan hubungan antara agama dengan negara. Pancasila adalah jalan tengah dalam menjembatani berbagai kepentingan individu maupun kelompok dalam kerangka Negara Kesatuan Republik Indonesia. Pancasila merupakan hasil konsensus penting dari para pendiri bangsa sebagai upaya untuk mentransformasi nilainilai trandisional menjadi nilai-nilai nasional.

Jika demikian, maka berteologi dalam konteks Indonesia, terutama sebagai upaya mengkonstruksi hubungan antara agama dan negara secara kontekstual, harus dapat dipahami bukan hanya sekedar sebagai alat untuk mencari titik temu antara berbagai kepentingan dalam kerangka suatu negara, melainkan juga sebagai upaya sistematis dalam merangkai kemajemukan bangsa. Pada titik ini, fakta sosial kemajemukan di Indonesia harus dilihat sebagai kekayaan yang memperkaya hubungan antara agama dan negara. Perbedaan agama dan keyakinan bukan menjadi cela terciptanya konflik sosial yang menyebabkan tereduksinya hubungan ideal antara agama dan negara, melainkan perbedaan-perbedaan tersebut harus tertenun (texture) dalam satu dasar hidup bersama (Pancasila) yang akan mengokohkan eksistensi negara Indonesia. Dengan dasar pemikiran demikian, maka Indonesia dapat dikatakan telah menjadi negara yang Injili, syari'at, dan kontekstual secara teologis. Tidak diperlukan lagi perdebatan-perdebatan dogmatis yang cenderung akan mendeferensiasikan kehidupan masyarakat Indonesia. Perbedaan agama, kepercayaan dan dogma telah dipersatukan dalam satu konsensus bersama yakni Pancasila itu sendiri.

Dengan kenyataan demikian yang telah menempatkan Indonesia sebagai negara yang "injili" dan kontekstual, maka ada beberapa bentuk panggilan orang Kristen dalam konteks Indonesia yakni: Menjaga eksistensi Pancasila sebagai bentuk konsensus bersama dan Indonesia sebagai rumah bersama; Mendukung secara aktif berbagai upaya untuk menjaga kesetaraan masyarakat didepan hukum; Menjunjung tinggi nilai-nilai kemanusiaan sehingga dapat melepaskan diri dari segala bentuk diskriminasi dan penindasan; Selalu memperjuangkan demokrasi dan hak asasi manusia; Mengawasi perilaku pemerintah agar tidak menyimpang dari hakikat keterpanggilannya sebagai abdi Allah yakni mendatangkan damai sejahtera bagi seluruh ciptaan Tuhan; Memastikan hubungan antara agama dan negara selalu berada dalam koridor konstitusi; Melepaskan tenunan dogtrinal agama yang eksklusif dan menggunakan pakaian yang lebih kontekstual dalam kerangka Indonesia. 
Dengan panggilan tersebut, orang-orang Kristen di Indonesia tidak saja menjadikan dirinya sebagai warga "Kerajaan Allah" tetapi juga warga negara Indonesia yang bertangung jawab dan berkepribadian. Kompetensi kekeristenan tersebut dapat terwujud dengan baik dalam kerangka pemikiran kebangsaan jika format keterlibatannya terwujud secara kontekstual dan kritis. Di sinilah letak pemahaman yang paling mendasar tentang bagaimana mengusahakan teologi yang kontekstual dalam rangka menata hubungan yang kondusif dan produktif antara agama dan negara di Indonesia. Agama-agama di Indonesia harus merumuskan teologi baru dalam lingkaran dialog antara teks kitab suci dan teks lingkungan sosial. Dengan mendialogkan kedua aspek tersebut maka interaksi multikultural dapat tertenun secara indah dalam sejarah peradaban bangsa Indonesia. Upaya serius untuk mewujudkan hal tersebut telah terpatri indah dalam perumusan dasar negara yang dikenal sebagai Pancasila. Pancasila adalah harapan sekaligus kenyataan tentang keterhubungan yang harmonis antara agama dan negara. Keterhubungan itu dikonstruksikan berdasarkan pemikiran yang bersifat kontekstual dan ideal.

\section{Kesimpulan}

Kesimpulan dari pembahasan ini adalah:

Pertama, hubungan antara agama dan negara harus dipahami sebagai hubungan yang bersifat konstruktif dan kontekstual. Hal ini berarti hubungan antara agama dan negara harus terus didorong untuk saling melengkapi dan membangun kohesifitasnya. Hubungan antara agama dan negara tidak boleh dipahami sebagai hubungan yang saling memanfaatkan ataupun saling menjauhi (bersifat distinktif). Kedua, Hubungan antara agama dan negara juga tidak akan luput dari berbagai perbedaan dan persinggungan yang terjadi. Agama dan negara adalah dua wilayah yang bersifat otonom sekaligus mekanis. Otonom sebab masing-masing memiliki paranan yang berbeda-beda, tetapi sekaligus mekanis karena keduanya diikat oleh solidaritas sosial yang sama. Ketiga, dalam padangan iman Kristen, baik agama maupun negara merupakan manifestasi dari kehadiran Tuhan di tengah-tengah umat manusia. Karenanya sebagai hamba Tuhan, baik agama maupun negara berkewajiban untuk mencerminkan dan menyebarluaskan sifat-sifat Allah itu sendiri yakni kasih, kebenaran, keadilan, nir-kekerasan, bertangungjawab dan kepedulian. Baik agama maupun negara merupakan alat Allah dalam menjembatani berbagai perbedaan umat manusia. Keempat, Dalam konteks Indonesia, hubungan antara agama dan negara harus dipahami dalam rentetan peristiwa sejarah yang melahirkan dasar negara sebagai buah dari inklusifitas pimikiran pendiri bangsa. Pancasila sebagai dasar negara adalah jawaban terhadap kemajemukan bangsa yang telah menjadi hakikat dari keberadaan Indonesia itu sendiri. Menempatkan pancasila sebagai dasar negara adalah bentuk konsensus yang paling arif dalam menjembatani hubungan antara agama dan negara secara kontekstual. Kelima, Hubungan antara agama dan negara di Indonesia harus berkembang secara kontekstual dalam kerangka pemikiran yang pluralis. Hal ini berarti baik agama maupun negara didorong untuk memiliki spirit yang sama yakni menghidupkan semangat persatuan dan kesatuan dalam perbedaan. Semangat tersebut harus menjadi warisan luhur bangsa Indonesia yang diturunkan dari generasi ke generasi. 


\section{Referensi}

Abdillah, Masykuri. "Hubungan Agama Dan Negara Dalam Konteks Modernisasi Politik Di Era Reformasi." AHKAM : Jurnal Ilmu Syariah 13, no. 2 (2013): 247-258.

Althaus, Paul.The Theology of Martin Luther. Philadelphia: Fortress Press, 1966.

Anshari. Piagam Jakarta 22 Juni 1945. Jakarta: Rajawali Press, 1986.

Ariarajah Wesley S. The Bible and People of Other Faiths. Hong Kong: WSCF Asia, 1985.

Berkhof dan Enklaar. Sejarah Gereja. Jakarta: BPK Gunung Mulia, 2001.

Bevens, B. Stephen. Models of Conntextual Theology: Faith and Culture. New York: Orbis Book, 1996.

Bua, Piter Randan, David Samiyono, and Tony Christian Tampake. "Misi Gereja Dalam Mewujudkan Keadilan Sosial: Sebuah Perspektif Dari Sila Kelima Pancasila." KURIOS (Jurnal Teologi dan Pendidikan Agama Kristen) 5, no. 2 (2019): 109124. http://www.sttpb.ac.id/e-journal/index.php/kurios/article/view/97/71.

Darmaputra, Eka. Pancasila: Identitas dan Modernitas. Jakarta: BPK Gunung Mulia, 1987.

Enss, Paul. Moody Hand Book of Theology. Chicago: Moody Press, 1989.

Griffiths, Michael. Gereja dan Panggilannya Dewasa Ini. Jakarta: 1991.

Hans kung \& David tracy. Paradigm Change in Theology. New York: Edinburg, 1989.

Kamus Besar Bahasa Indonesia (KBBI) Kamus versi onlinel daring (dalam jaringan), diunduh hari Rabu tanggal 14 Agustus 2019.

Knitter, Paul F. Introducing Theologies of Religions. New York: Orbis Books, 2002.

Kristianto, Paulus Eko. "Dunamis : Jurnal Teologi Dan Pendidikan Kristiani Merumuskan Etika Politik Kristen Dalam Era Gangguan Terorisme Di Indonesia.” DUNAMIS: Jurnal Teologi dan Pendidikan Kristiani 3, no. 2 (2019): 223-240.

Lay, Cornelis. "Kekerasan Atas Nama Agama: Perspektif Politik." Jurnal Ilmu Sosial dan Ilmu Politik 13, no. 1 (2009): 1-19.

LAI. Alkitab Dengan Kidung Jemaat. Jakarta: Percetakan LAI, 2009.

Marantika, Chris. Principle and Practice of World Missions, Including a Closer Look in an Islamic Context. Yogyakarta: Iman Press, tt.

Neisel. The Theology of Calvin. London: Lutterworth Press, 1956.

Pranarka. Sejarah Pemikiran Tentang Pancasila. Jakarta: CSIS, 1988.

Purwanto, Edi. "Peran Ekonomi, Politik, Dan Sosial Dalam Kekerasan Atas Nama Agama." DUNAMIS: Jurnal Teologi dan Pendidikan Kristiani 4, no. 1 (2019): 111126.

Sari, Endang. "Kebangkitan Politik Identitas Islam Pada Arena Pemilihan Gubernur Jakarta.” Kritis: Jurnal Ilmu Sosial dan Ilmu Politik 2, no. 2 (2016): 145-156.

Siahaan, Harls Evan. "Mengajarkan Nasionalisme Lewat Momentum Perayaan Paskah : Refleksi Kritis Keluaran 12 : 1-51.” Dunamis : Jurnal Teologi dan Pendidikan Kristiani 1, no. 2 (2017): 140-155. https://www.sttintheos.ac.id/ejournal/index.php/dunamis/article/view/119.

Siahaan, Harls Evan R. "Memaknai Pentakostalisme Dalam Maksud Politis Lukas: Analisis Kisah Para Rasul 1:6-8." DUNAMIS: Jurnal Teologi dan Pendidikan Kristiani 3, no. 1 (2018): 52-73. https://sttintheos.ac.id/ejournal/index.php/dunamis/article/view/174/140.

Simorangkir Dkk. Mempercakapkan Relasi Agama dan Negara. Jogjakarta: Pustaka Pelajar, 2011.

Subagyo, A. B,. Pengantar Riset Kuantitatif dan Kualitatif (Bandung: Yayasan Kalam Hidup, 2004). 
Sugirtharajah. Postcolonial Criticism and Biblical Interpretation. Oxford: Oxford University Press, 2002.

Tim Penyunting. Risalah Sidang BPUPKI dan PPKI. Jakarta Sekretaris Negara RI, 1995.

Timothy. Marthin Luther's Basic Theological Writings. Minneapolis: Fortress Press, 1989.

Titaley, John, Nilai -Nilai Dasar Yang Terkandung Dalam Pembukaan UUD 1945. Salatiga: Fakultas Teologi UKSW, 1999.

Yewangoe, Andreas A. Piagam Djakarata dan Syariat Islam; Urgensi dan Konsekuensinya. Jakarta: Yayasan Bina Darma dan Nisita, 2003.

Yoder, John. The Politics of Jesus. Michigan: William B. Eerdman Publishing House Company, 1972.

Yudhi Kawangung, Visio Dei: Jurnal Teologi Kristen, Diskursus Kerukunan Sosial Dalam Perspektif Masyarakat Kristen Di Indonesia: Rekonsiliasi Pasca Pemilu 2019, Luwuk Banggai, 141-160.

Zaluchu, Sonny. "Sudut Pandang Etika Kristen Menyikapi Pembangkangan Sipil (Civil Disobedience)." DUNAMIS: Jurnal Teologi dan Pendidikan Kristiani 3, no. 1 (2018): 24. 